- FINANSE I PRAWO FINANSOWE.

- Journal of Finance and Financial Law

Wrzesień/September 2018 • vol. 3(19): 41-53

https://doi.org/10.18778/2391-6478.3.19.04

\title{
EDUKACJA W ZAKRESIE FUNKCJONOWANIA SYSTEMU PODATKOWEGO JAKO PRZEJAW OCHRONY PRAW PODATNIKA
}

\author{
Natalia Ołówko \\ Wydział Ekonomiczny \\ Uniwersytet Marii Curie-Skłodowskiej w Lublinie
}

\section{Streszczenie}

Artykuł ma na celu przybliżenie praw przysługujących podatnikom zawartych zarówno w ustawie zasadniczej, jak i w Ordynacji podatkowej oraz skonfrontowanie ich ze stopniem wiedzy podatników o podstawach funkcjonowania systemu podatkowego. Pokazanie, jak istotny jest problem nieświadomości społeczeństwa w kontekście znajomości podatków na podstawie wyników przeprowadzonych badań ma również zwrócić uwagę na potrzebę przeprowadzania akcji i inicjatyw edukacyjnych. Projekty tego typu, przeprowadzane głównie przez Ministerstwo Finansów i Krajową Izbę Doradców Podatkowych są niezwykle istotne i powinny zostać zintensyfikowane w ramach zwiększania świadomości podatników o obowiązkach oraz prawach, jakie im przysługują. W artykule zostają wymienione również przykłady takowych inicjatyw mających miejsce w przeszłości.

Słowa kluczowe: prawa podatników, system podatkowy w Polsce, edukacja podatkowa.

JEL Class: H200, H300. 


\section{WPROWADZENIE}

Podatki są elementem nieodzownym, jeśli chodzi o funkcjonowanie w społeczeństwie. Mogą mieć one charakter bezpośredni lub pośredni, jednakże w pewien sposób dotykają każdego uczestnika życia społecznego. Świadczą o tym także liczby. Przykładowo, w 2016 roku odnotowano 25103630 podatników podatku PIT, opodatkowujących swoje dochody przy zastosowaniu skali podatkowej [Informacja dotyczaca rozliczenia podatku dochodowego..., 2017: 4]. Nie można też zapominać, iż z podatkami mamy do czynienia podczas wykonywania tak prozaicznych czynności, jak np. zakupy czy korzystanie z różnorakich usług. Ponadto, odwołując się do literatury przedmiotu „historia myśli podatkowej dowodzi, że pobór podatku towarzyszy niezmiennie każdej działalności zarobkowej człowieka i każdemu procesowi gospodarczemu" [Gomułowicz i Małecki 2011: 83]. W związku z tak szerokim oddziaływaniem systemu podatkowego na ogół społeczeństwa, koniecznym wydaje się wyróżnienie konkretnych praw i obowiązków podatników, a także upowszechnianie wiedzy w tym zakresie. Kwestia ta jest poruszana zarówno na szczeblach międzynarodowych, jak i krajowych. Jest to istotny aspekt, zwłaszcza, że istnieje przeświadczenie, iż polski system podatkowy jest nieprzyjazny i niesprawiedliwy dla podatników, co może wynikać z braku świadomości i odpowiedniej wiedzy o funkcjonujących rozwiązaniach. W przypadku Polski, główne prawa i obowiązki można znaleźć w Ordynacji podatkowej, czyli ustawie regulującej ogólne zagadnienia prawa podatkowego. W związku z tym, że zagadnienia podatkowe regulowane są przez wiele źródeł, m.in. przepisy krajowe, prawo międzynarodowe, konwencje czy też umowy podatkowe, istotne jest wsparcie podatników i uświadamianie im obowiązków, jakie wynikają ze wspomnianych źródeł oraz ich praw. Wagę tej kwestii podkreśla także fakt, iż w nadrzędnym akcie normatywnym będącym jednym ze źródeł prawa finansowego, czyli ustawie zasadniczej, można wyróżnić konstytucyjne gwarancje ochrony podatnika, przejawiające się np. w wyłącznie ustawowym trybie wprowadzania podatków i innych danin publicznych oraz określaniu $\mathrm{w}$ formie ustawy pełnej konstrukcji prawnej podatku, jego podmiotu, wysokości stawek, zasad przyznawania ulg i umorzeń podatkowych [Konstytucja Rzeczpospolitej Polskiej..., art. 217]. Istotą tego uregulowania jest zapewnienie należytych gwarancji praw podatnika wobec organów władzy publicznej. Na konieczność zwiększania wiedzy podatników w zakresie obowiązującego ich prawa wpływa też częsta zmienność przepisów. 


\section{PRZEJAWY OCHRONY PRAW PODATNIKÓW}

\subsection{Prawa podatnika zawarte $w$ Konstytucji}

Jak zostało wspomniane we wprowadzeniu, w ustawie zasadniczej ujęte zostały konstytucyjne gwarancje ochrony praw podatnika. W związku z tym, że podatnik jest podmiotem stosunku prawnopodatkowego, posiada swego rodzaju autonomię $\mathrm{w}$ relacji z fiskusem. Przejawia się to m.in. w prawie podatnika do wniesienia skargi do Trybunału Konstytucyjnego w przypadku naruszenia przysługujących mu praw [Konstytucja Rzeczpospolitej Polskiej..., art. 79].

Jednym $\mathrm{z}$ aspektów zawartym $\mathrm{w}$ ustawie zasadniczej jest ochrona prawna wolności człowieka [Konstytucja Rzeczpospolitej Polskiej..., art. 31, ust. 1]. Jej źródłem jest przyrodzona i niezbywalna godność człowieka [Konstytucja Rzeczpospolitej Polskiej..., art. 30]. Występują jednakże dopuszczalne ograniczenia praw i wolności, jeśli są one niezbędne dla zachowania bezpieczeństwa lub porządku publicznego [Konstytucja Rzeczpospolitej Polskiej..., art. 31, ust. 3]. Jest przy tym wymagane, by każde ograniczenie było proporcjonalne, legalne i celowe. Proporcjonalność ta ma wyrażać się w równowadze między stopniem ingerencji w prawa jednostki, a uzasadnioną potrzebą pojawiającą się w związku z usprawiedliwionym celem [Bojkowski 2004].

Kolejną istotną zasadą jest zasada równości wobec prawa. Konstytucja rozwija ją także poprzez wyróżnienie ogólnego prawa do równego traktowania przez władze publiczne [Konstytucja Rzeczpospolitej Polskiej..., art. 32, ust. 1]. Istnieje też zakaz dyskryminacji w życiu politycznym, społecznym lub gospodarczym z jakiejkolwiek przyczyny [Konstytucja Rzeczpospolitej Polskiej..., art. 32, ust. 1]. Warto przy tym zwrócić uwagę, iż równość nie jest jednoznaczna $\mathrm{z}$ jednakowym traktowaniem. Jej istotą jest bowiem takie same traktowanie osób znajdujących się w podobnej sytuacji, kiedy to nie istnieje racjonalne uzasadnienie do traktowania ich w odmienny sposób ${ }^{1}$.

Należy również wspomnieć o aspekcie ważnym dla podatników zawartym w 45. artykule Konstytucji RP, mówiącym o prawie do sprawiedliwego i jawnego rozpatrzenia sprawy przez właściwy, niezależny, bezstronny i niezawisły sąd bez zwłoki, która jest nieuzasadniona ${ }^{2}$. Na jego podstawie można twierdzić, iż każdy podatnik może wystąpić z roszczeniem o sądowne rozpa-

${ }^{1}$ Por. postanowienie z 7 listopada 2001 r., sygn. Ts 97/98, OTK ZU 2001, nr 8, poz. 282. [cyt. za:] Bojkowski [2004: 118].

${ }^{2}$ Konstytucja Rzeczpospolitej Polskiej z dnia 2 kwietnia 1997 r. [Dz.U. nr 78, poz. 483, art. 45], Por. postanowienie z 7 listopada 2001 r., sygn. Ts 97/98, OTK ZU 2001, nr 8, poz. 282. [cyt. za:] Bojkowski [2004: 118]. 
trzenie jego sprawy, a sąd ma wówczas obowiązek tę sprawę rozpatrzyć [Bojkowski 2004: 120].

Zasadą zawartą w konstytucji, a zdaniem T. Bojkowskiego zagrożoną przez regulacje podatkowe jest także prawo do prywatności. W ustawie zasadniczej można znaleźć je w artykule 47., mówiącym o tym, iż „każdy ma prawo do ochrony prawnej życia prywatnego, rodzinnego, czci i dobrego imienia oraz do decydowania o swoim życiu osobistym" [Konstytucja Rzeczpospolitej Polskiej..., art. 47]. Wspomniane zagrożenie tego prawa może wynikać z tego, iż zgodnie z tym co uznał Trybunał Konstytucyjny, „deklaracje majątkowe, o szczegółowej treści (co do przedmiotu, szacunku i czasu, w jakim majątek zgromadzono), $\mathrm{z}$ inkorporowanym $\mathrm{w}$ nich ryzykiem nierzetelności, ocenianym przez aparat administracyjny (co tworzy groźbę odpowiedzialności już za sam fakt nierzetelności, a nie za zatajenie dochodu)" nie są zgodne $\mathrm{z}$ art. $47 \mathrm{w}$ związku z art. 31 ust. 1 i art. 51 ust. 1 Konstytucji [Bojkowski 2004: 121]. Art. 51 mówi bowiem, że władze publiczne nie mogą pozyskiwać, gromadzić i udostępniać informacji o obywatelach, a każdy ma prawo dostępu do dotyczących go urzędowych dokumentów i zbiorów danych. Ponadto obywatelom przysługuje prawo żądania sprostowania i usunięcia niepełnych bądź nieprawdziwych informacji [Konstytucja Rzeczpospolitej Polskiej..., art. 51].

W kwestii praw podatników na odnotowanie zasługuje konstytucyjne prawo do własności, będące jednym z zawartych $\mathrm{w}$ ustawie zasadniczej praw ekonomicznych. Wskazuje ono również na podleganie własności, praw majątkowych oraz prawa dziedziczenia równej dla wszystkich ochronie prawnej [Konstytucja Rzeczpospolitej Polskiej..., art. 64]. W tym kontekście pewne kontrowersje może budzić zawarty w art. 84 Konstytucji obowiązek ponoszenia przez każdego ciężarów i świadczeń publicznych, w tym podatków, określonych w ustawie. Opierając się na orzecznictwie Trybunału Konstytucyjnego należy tu jednak zaznaczyć, że między prawami i obowiązkami zamieszczonymi w konstytucji istnieje ścisły związek, co potwierdza m.in. umieszczenie obu aspektów w jednym rozdziale. Uzasadnione jest to tym, iż „Bez obowiązków w stosunku do państwa (w tym obowiązków podatkowych) nie mogłaby istnieć państwowa ochrona praw własności ${ }^{3}$.

Dodatkowo, jak wspomniano we wprowadzeniu, o ochronie praw podatnika wynikającej z Konstytucji świadczy art. 217 ustawy zasadniczej - tylko i wyłącznie w drodze ustawy możliwe jest nałożenie podatków, innych danin publicznych, określanie podmiotów, przedmiotów opodatkowania i stawek podatkowych, a także zasad przyznawania ulg i umorzeń oraz kategorii podmiotów zwolnionych od podatków [Konstytucja Rzeczpospolitej Polskiej..., art. 217]. Według Trybunału Konstytucyjnego „wyłączność drogi ustawowej w nakłada-

${ }^{3}$ Por. wyrok z 16 kwietnia 2002 r., sygn. SK 23/01, OTK ZU 2002, nr 3A, poz. 26 [cyt. za:] Bojkowski [2004: 123]. 
niu podatków służy stworzeniu silniejszej ochrony proceduralnej praw podatnika wobec organów władzy publicznej, a zawarty w art. 217 Konstytucji nakaz określania w ustawie istotnych elementów obowiązku podatkowego należy rozumieć jako nakaz szczególnej precyzji przy określaniu podmiotów opodatkowania, przedmiotów opodatkowania oraz stawek podatkowych [Wyrok TK z dnia 27 listopada 2007 r., sygn. akt SK 39/06, LEX 318047].

\subsection{Prawa podatnika zawarte w Ordynacji podatkowej}

Ordynacja podatkowa to podstawowy akt regulujący ogólne zasady istotne z punktu widzenia wszystkich podatków, takie jak moment powstawania i wygasania zobowiązań podatkowych, przebieg postępowania podatkowego, kontroli podatkowej i czynności sprawdzających. W ramach normalizowania tychże zagadnień, uwzględniona została także rola podatników w tych procesach, w tym ich prawa. Są one sformułowane tu bardziej szczegółowo niż w ustawie zasadniczej.

Od dnia 1 stycznia 2016 r. w życie weszła zasada ,in dubio pro tributario”, zawarta w artykule 2a Ordynacji podatkowej. Mówi ona, iż „niedające się usunąć wątpliwości co do treści przepisów prawa podatkowego rozstrzyga się na korzyść podatnika" [Ustawa z dnia 29 sierpnia 1997 r. ..., art. 2a]. W związku z jej wprowadzeniem, przez Ministra finansów została wydana interpretacja ogólna, w której zwraca uwagę, iż implementowana zasada dotyczy wyłącznie wątpliwości co do treści przepisów prawa, nie zaś co do stanu faktycznego. Ponadto, mimo iż artykuł 2a Ordynacji podatkowej w swej treści odnosi się jedynie do podatnika, nie ma żadnych przeciwskazań do stosowania tegoż przepisu w sprawach innych niż podatnik podmiotów obciążanych obowiązkami wynikającymi z przepisów prawa podatkowego, czyli w sprawach płatników, inkasentów, następców prawnych podatnika czy też osób trzecich odpowiedzialnych za cudze zobowiązania podatkowe. Dodatkowo Minister finansów w wydanym dokumencie definiuje pojęcie „korzyść podatnika”, które to uznaje za „optymalne dla niego rozwiązanie prawne spośród tych, które zarysowały się $\mathrm{w}$ trakcie wykładni przepisu". W przypadku, gdy organ podatkowy ma możliwość zastosowania $\mathrm{w}$ danej sprawie więcej niż jedną, korzystną i równorzędną dla podatnika interpretację przepisu, jest zobligowany do wyboru interpretacji korzystniejszej dla podatnika. Podatnik ma również prawo samodzielnego wskazania korzystniejszego według siebie rozwiązania, np. za pośrednictwem deklaracji podatkowej czy prezentując swoje stanowisko $\mathrm{w}$ toku postępowania podatkowego [Interpretacja ogólna ministra finansów..., PK4.8022.44.2015]. 
Bardziej szczegółowym prawem podatnika, odnoszącym się do konkretnej sytuacji, jest prawo do zwrotu nadpłaty podatku. Wyrażone jest ono m.in. w art. 75 Ordynacji podatkowej stanowiącym o możliwości podatnika do złożenia wniosku o stwierdzenie nadpłaty podatku, w przypadku, gdy kwestionuje on zasadność lub wysokość pobranego podatku [Ustawa z dnia 29.08.1997 r, .., art. 75]. Stwierdzona nadpłata, łącznie z jej oprocentowaniem z urzędu podlega zaliczeniu na poczet zaległości podatkowych oraz bieżących zobowiązań podatkowych, a w przypadku ich braku, dokonywany jest jej zwrot z urzędu, chyba że zostanie złożony przez podatnika wniosek o zaliczenie nadpłaty w całości lub w części na poczet przyszłych zobowiązań podatkowych [Ustawa $\mathrm{z}$ dnia 29 sierpnia 1997 r. ..., art. 76, ust. 1].

Podatnik ma również prawo do żądania wydania mu potrzebnego zaświadczenia, w przypadku wymagania przez określony przepis prawa urzędowego potwierdzenia konkretnego stanu prawnego lub faktu, lub gdy ubieganie się wynika z interesu prawnego podatnika. Wydane zaświadczenie potwierdza stan prawny lub faktyczny istniejący w dniu jego wydawania, powinno być też wydane bez zbędnej zwłoki, nie później niż w ciągu 7 dni od złożenia wniosku o wydanie zaświadczenia [Ustawa z dnia 29 sierpnia 1997 r. ..., art. 306a].

Kolejnym istotną możliwością, jaka jest stwarzana podatnikowi, jest dane mu prawo do ulg w spłacie zobowiązań podatkowych. Zgodnie z artykułem 67a Ordynacji podatkowej, wyróżniamy 3 rodzaje ulg w spłacie zobowiązań podatkowych:

- odroczenie terminu płatności podatku, zapłaty zaległości podatkowej wraz z odsetkami za zwłokę lub też odsetek od nieuregulowanych w terminie zaliczek na podatek,

- rozłożenie na raty zapłaty podatku, zapłaty zaległości podatkowej wraz $\mathrm{z}$ odsetkami za zwłokę lub też odsetek od nieuregulowanych w terminie zaliczek na podatek,

- umorzenie w całości lub części zaległości podatkowych, odsetek za zwłokę lub opłaty prolongacyjnej, przy czym powoduje to także umorzenie odsetek za zwłokę w całości lub w takiej części, w jakiej została umorzona zaległość podatkowa.

Niezbędne przy tym jest, by wniosek podatnika o uzyskanie ulgi w spłacie zobowiązania podatkowego był uzasadniony jego ważnym interesem lub też interesem publicznym [Ustawa z dnia 29 sierpnia 1997 r. ..., art. 67a].

Czynnikiem ułatwiającym podatnikowi złożenie deklaracji podatkowej, jest możliwość podpisania jej przez pełnomocnika (o ile odrębne ustawy nie stanowią inaczej). Dotyczy to również deklaracji składanej za pomocą środków komunikacji elektronicznej. Pełnomocnictwo należy złożyć organowi podatkowemu właściwemu w sprawach podatku, którego dana deklaracja dotyczy - może być ono złożone również w formie dokumentu elektronicznego. Należy jednak 
pamiętać, że w przypadku wymagania przez prawo podatkowe podpisania deklaracji przez więcej niż jedną osobę, pełnomocnictwo dochodzi do skutku tylko w przypadku udzielenia go przez wszystkie wymagane osoby [Ustawa z dnia 29 sierpnia 1997 r. ..., art. 80a].

Ważne jest również dla podatnika, aby miał świadomość przysługującej mu możliwości korekty złożonej uprzednio deklaracji. Korekty dokonuje się poprzez złożenie deklaracji korygującej [Ustawa z dnia 29 sierpnia 1997 r. ..., art. 81]. Należy jednak pamiętać, że wspomniane prawo jest zawieszane w przypadku trwania postępowania podatkowego czy też kontroli podatkowej - w zakresie objętym postępowaniem lub kontrolą [Ustawa z dnia 29 sierpnia 1997 r. ..., art. 81b, ust. 1, pkt. 1].

Przejawem ochrony praw podatnika zawartym w Ordynacji podatkowej jest ponadto objęcie tajemnicą skarbową indywidualnych danych zawartych $\mathrm{w}$ deklaracjach lub innych składanych przez podatnika dokumentach [Ustawa z dnia 29 sierpnia 1997 r. ..., art. 293, ust. 1]. Ujawnienie informacji objętych tajemnicą skarbową przez osoby zobowiązane do jej zachowania jest zagrożone karą pozbawienia wolności do 5 lat [Ustawa z dnia 29 sierpnia 1997 r. ..., art. 306, ust. 1].

W przypadku wątpliwości podatnika odnośnie zastosowania przepisów prawa podatkowego w jego konkretnej sytuacji, ma on prawo wystąpić do Dyrektora Krajowej Informacji Skarbowej z wnioskiem o wydanie interpretacji indywidualnej. Warunkiem jest wyczerpujące przedstawienie we wniosku zaistniałego stanu faktycznego lub zdarzenia przyszłego, a ponadto opisanie stanowiska podatnika odnośnie oceny prawnej opisywanego stanu faktycznego lub przyszłego zdarzenia. Należy jednocześnie pamiętać, iż nie jest możliwe wydanie interpretacji indywidualnej w zakresie elementów stanu faktycznego będących w dniu złożenia wniosku o interpretację przedmiotem postępowania podatkowego, kontroli podatkowej czy celno-skarbowej. Bezprzedmiotowość wniosku stwierdza się również, gdy opisany w nim stan faktyczny lub zdarzenie przyszłe odpowiadają zagadnieniu będącemu przedmiotem wydanej interpretacji ogólnej [Ustawa z dnia 29 sierpnia 1997 r. ..., art. 14b]. Wniosek o wydanie interpretacji indywidualnej podlega opłacie w wysokości 40 zł, którą to należy uiścić w terminie 7 dni od daty złożenia tegoż wniosku. Kwota ta jest pobierana od każdego pojedynczego odrębnego stanu faktycznego czy zdarzenia przyszłego opisanego we wniosku [Ustawa z dnia 29 sierpnia 1997 r. ..., art. 14f, ust. 1, ust. 2]. Interpretację indywidualną wydaje się bez zbędnej zwłoki, jednak nie później niż w ciągu 3 miesięcy od dnia otrzymania wniosku [Ustawa z dnia 29 sierpnia 1997 r. ..., art. 14d]. 


\section{2. ŚWIADOMOŚĆ PODATNIKÓW O SWOICH PRAWACH I SPOSOBIE FUNKCJONOWANIA SYSTEMU PODATKOWEGO}

Pomimo istniejących uregulowań odnośnie praw podatników, z czego niektóre zostały przedstawione we wcześniejszej części artykułu, podatnicy uważają funkcjonujący obecnie system podatkowy za nieprzyjazny i niesprawiedliwy. Negatywnie o systemie podatkowym wypowiadają się przedsiębiorcy. Biorąc pod uwagę wyniki badania dotyczącego systemu podatkowego w Polsce przeprowadzonego 9 stycznia 2018 roku wśród uczestników VIII Kongresu Podatków i Rachunkowości KPMG, spośród pięciu poruszonych w nim aspektów najsłabiej wypada stabilność przepisów podatkowych - w skali od 1 do 5 (gdzie 1 to „bardzo słabo”, a 5 - „,bardzo dobrze”) została ona oceniona na poziomie tylko 1,6 - jest to spadek o 0,2 w porównaniu do badania sprzed roku [Polski system podatkowy..., 2018]. Opierając się na raporcie z badania ilościowego przeprowadzonego w lutym 2017 roku na zlecenie Związku Przedsiębiorców i Pracodawców, 83\% badanych wskazało na niesprawiedliwość systemu podatkowego, a $85 \%$ scharakteryzowało go określeniem „nieprzyjazny” [Raport z badania ilościowego..., 2017: 9]. Takie wyniki mogą pobudzać do wysnucia wniosków mówiących o niedoskonałości funkcjonujących praw podatników. Przyglądając się jednak bliżej wynikom przeprowadzonego badania, bardziej trafnym wnioskiem okazuje się niewystarczające wyedukowanie społeczeństwa w kontekście wiedzy o podstawach funkcjonowania systemu podatkowego w Polsce.

Świadomość płacenia podatków

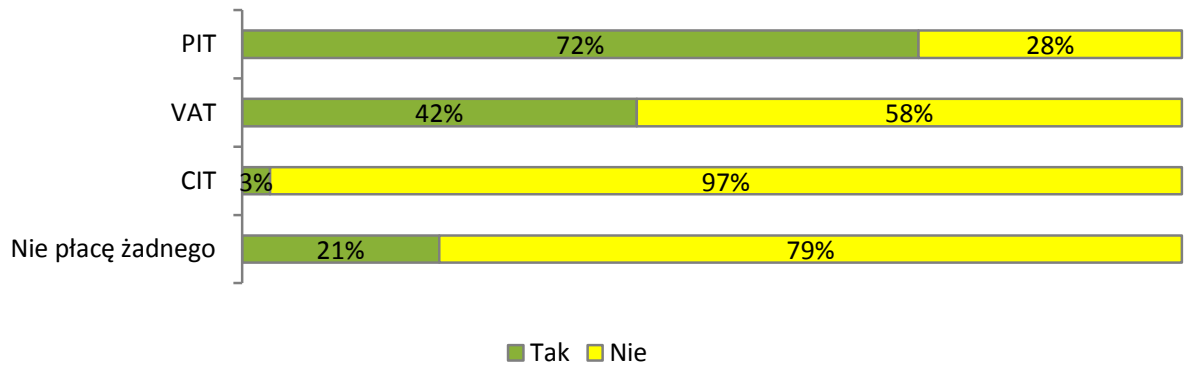

Wykres 1. Odpowiedzi badanych na pytanie „Które z podanych podatków płacisz jako osoba prywatna?

Źródło: opracowanie własne na podstawie Raportu z badania ilościowego..., 2017. 
Jak możemy zobaczyć na wykresie 1, świadomość Polaków odnośnie płaconych przez nich podatków jest bardzo niska. Na szczególną uwagę zasługuje fakt, iż aż $21 \%$ badanych odpowiedziało, iż, ich zdaniem, nie płaci żadnego podatku, ani PIT-u, ani CIT-u, a nawet VAT-u. Biorąc pod uwagę, iż w badaniu brały udział wyłącznie osoby pełnoletnie wynik ten jest dość niepokojący [Raport z badania ilościowego..., 2017: 12].

\section{Znajomość podatków a ich rozumienie}

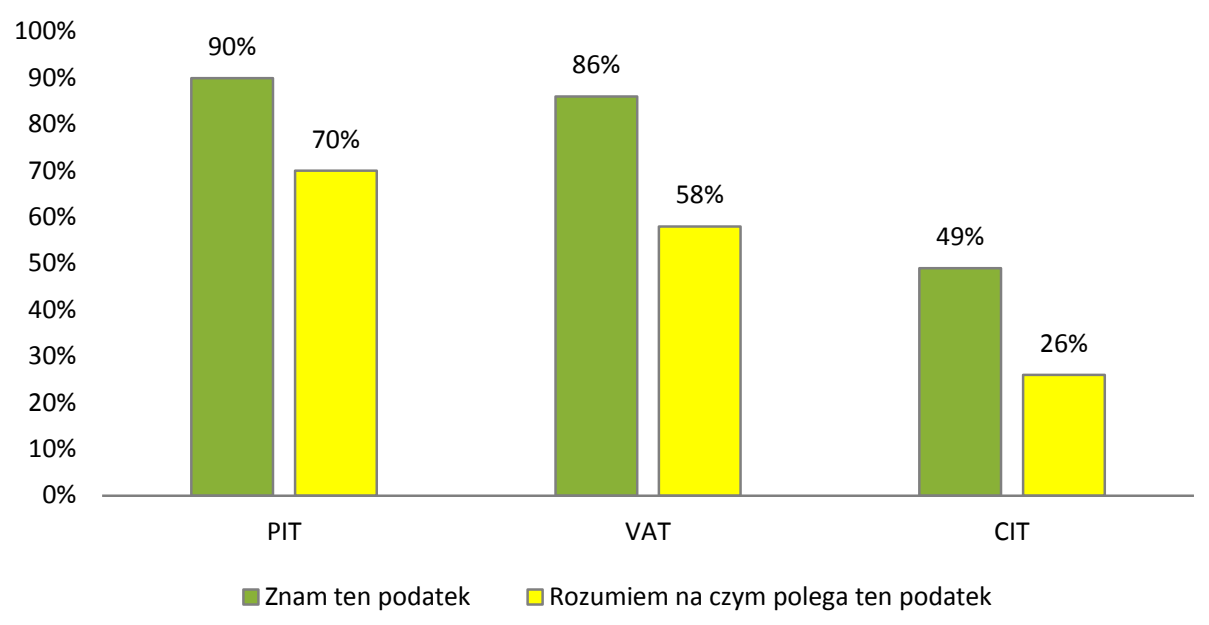

Wykres 2. Odpowiedzi badanych na pytania „Które z podanych podatków znane Ci są choćby tylko ze słyszenia?”; „Które z tych podatków są Ci znane w taki sposób, że rozumiesz dokładnie na czym polegają?"

Źródło: opracowanie własne na podstawie Raportu z badania ilościowego..., 2017.

Jeśli chodzi o samą znajomość podatków, wyniki również nie są optymistyczne. O ile $90 \%$ badanych deklaruje, iż zna podatek PIT, to już tylko $70 \%$ przyznaje, że rozumie na czym ten podatek polega. Jeszcze gorzej sprawa wygląda w przypadku podatku od towarów i usług. $86 \%$ badanych odpowiedziało, że zna ten podatek, jednakże jedynie 58\% sądzi, iż rozumie funkcjonowanie tegoż podatku [Raport z badania ilościowego..., 2017: 10, 11]. Ten odsetek może być jeszcze mniejszy, biorąc pod uwagę, że zgodnie $\mathrm{z}$ danymi przedstawionymi na wykresie 1 , tylko $42 \%$ badanych odpowiedziało twierdząco na pytanie czy płacą podatek VAT. 


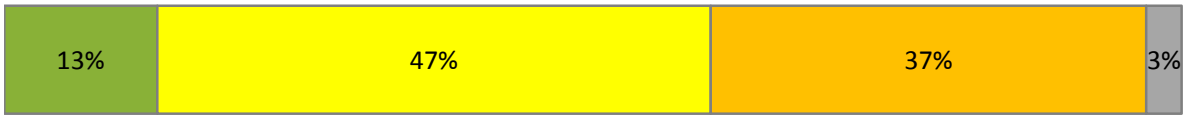

$\square$ Bardzo łatwe $\square$ Dosyć łatwe $\square$ Dosyć trudne $\square$ Bardzo trudne

Wykres 3. Odpowiedzi badanych na pytanie: „Jak oceniasz przygotowanie corocznego rozliczenia podatkowego?"

Źródło: opracowanie własne na podstawie Raportu z badania ilościowego..., [2017].

Na podstawie wyników badań opublikowanych we wspomnianym raporcie, możemy również stwierdzić, że rozliczanie podatków nie jest łatwe dla tych osób spośród badanych, które pracują w oparciu o umowy. 40\% respondentów uznało tę czynność za sprawiającą im trudności. Grupę tę tworzą głównie osoby z wykształceniem podstawowym i zawodowym, a w rozróżnieniu na płeć - głównie mężczyźni (o 13 p.p. więcej mężczyzn niż kobiet) [Raport z badania ilościowego..., 2017: 14].

Wyniki przeprowadzonego badania jednoznacznie wskazują na małą wiedzę Polaków o podatkach, z którymi mają styczność na co dzień. Brak znajomości podstawowych mechanizmów funkcjonowania systemu podatkowego pozwala wysnuć wniosek, iż tym bardziej nikły jest stopień świadomości podatników o przysługujących im prawach. Nieświadomość może być zatem traktowana jako czynnik wpływający na nie całkiem obiektywne oceny systemu podatkowego, uznanego za niesprawiedliwy i nieprzyjazny.

\section{PRZYKŁADY INICJATYW EDUKACYJNYCH W ZAKRESIE UPOWSZECHNIANIA WIEDZY O FUNKCJONOWANIU POLSKIEGO SYSTEMU PODATKOWEGO}

Na podstawie wyników badań przytoczonych w poprzedniej części artykułu można stwierdzić, iż istnieje silna potrzeba edukacji społeczeństwa w zakresie wiedzy o podatkach. Ministerstwo Finansów w zakresie popularyzacji znajomości tych zagadnień podejmuje różne inicjatywy. Jako przykład mogą być przedstawione publikowane broszury informacyjne. W 2014 roku przez Ministerstwo Finansów została opublikowana jedna $\mathrm{z}$ nich o tytule „Prawa i obowiązku podatnika", wyjaśniająca w przystępny sposób ważne zagadnienia dla każdego podatnika. Miało się to przyczynić do zwiększenia świadomości społecznej o prawach przysługujących każdemu podatnikowi, a tym samym do skuteczniejszej ich ochrony. 
Ponadto na stronie internetowej Ministerstwa można znaleźć informacje o przeprowadzonych bądź nadal trwających akcjach edukacyjnych. Jako przykład można podać „Loterię Paragonową” trwającą w latach 2015-2016. Celem inicjatywy było uświadomienie konsumentom ich roli w uczciwym obrocie gospodarczym i upowszechnienie nawyku brania i wydawania paragonów fiskalnych, dzięki czemu zniwelowane miało być zjawisko ukrywania obrotów przez przedsiębiorców [www2]. Podobnym celom służyła przeprowadzana od września do listopada 2016 roku akcja ,Weź paragon ze sobą” [www3].

Ministerstwo Finansów organizuje także akcje kierowane do młodzieży. Jak dotychczas zostały przeprowadzone 3 edycje projektu ,Finansoaktywni”, z czego ostatnia dotyczyła zagadnienia uczciwego płacenia podatków. Celem programu było zwiększenie świadomości młodzieży na temat wpływu podatków na ich najbliższe otoczenie, a także wiedzy w kontekście przyszłego funkcjonowania w społeczeństwie jako dorosły obywatel [www4].

Najbardziej znanym projektem edukacyjnym jest jednak ,Wielki test o podatkach" organizowany wspólnie przez Ministerstwo Finansów i TVP. Jak dotychczas miały miejsce 3 edycje testu. Odbywa się on pod koniec kwietnia, zatem w okresie rozliczania podatku dochodowego, kiedy to wiedza o zagadnieniach podatkowych jest podatnikom szczególnie potrzebna. Zgodnie z publikacją na stronie internetowej Ministerstwa, podczas testu pokazywane są udogodnienia proponowane przez administrację podatkową, aby obowiązki wobec fiskusa „uczynić łatwiejszymi i przyjemniejszymi” [www5].

Inną formą pomocy przy rozliczeniu rocznego zeznania podatkowego jest ogólnopolska kampania informacyjna „,szybki PIT”, która dotychczas miała już 9 edycji. W jej ramach podatnikom udostępnianych jest wiele narzędzi mających na celu udzielić pomocy przy rozliczeniu. Sa to m.in. dyżury telefoniczne ekspertów Ministerstwa Finansów, wydłużone godziny pracy, a nawet punkty rozliczeń w galeriach handlowych. Ponadto akcja ma na celu spopularyzowanie wysyłanie deklaracji drogą elektroniczną. W jej ramach przygotowywane są także specjalne plakaty i broszury informacyjne promujące wiedzę na temat rozliczeń oraz aktualnych ulg podatkowych [www6].

Instytucją włączającą się w przeprowadzanie inicjatyw edukacyjnych skierowanych do podatników jest także Krajowa Izba Doradców Podatkowych, organizująca „Akcję PIT - doradcy podatkowi dla osób z niepełnosprawnością”. Polega ona na darmowej pomocy doradców skierowanej do osób z niepełnosprawnością i ich rodzin [www7]. Dodatkowo wiele akcji organizowanych jest indywidualnie przez regionalne oddziały Krajowej Izby Doradców Podatkowych, przykładowo w 2017 r. wielkopolski oddział KIDP przeprowadził akcję non profit „Pomoc w wypełnianiu PITów”. Jej celem miało być udzielenie pomocy rencistom, emerytom i osobom niezamożnym z województwa wielkopolskiego [www1]. 


\section{PODSUMOWANIE}

W ustawach regulujących polskie prawo podatkowe można znaleźć wiele przepisów odnoszących się do praw, jakie przysługują podatnikowi. Pomimo to, wyniki przeprowadzanych badań pokazują bardzo negatywny odbiór obecnego kształtu systemu podatkowego opisując jako nieprzyjazny podatnikowi oraz niesprawiedliwy. Słabe oceny niekiedy mogą wynikać także z braku fundamentalnej wiedzy o mechanizmie funkcjonowania systemu podatkowego, na co wskazują odpowiedzi respondentów. Potwierdzają one ponadto postawioną we wstępie tezę o braku wystarczającej wiedzy i świadomości podatkowej w społeczeństwie. Daje to wyraźny sygnał, że niezbędne są inicjatywy upowszechniające wiedzę przede wszystkim o podstawowych zasadach funkcjonowania podatków, z którymi na co dzień mamy do czynienia, bowiem społeczeństwo nie jest $\mathrm{w}$ pełni świadome ich realnego oddziaływania. Jest to również konieczne w kontekście znajomości swoich praw przez podatników, które to są opisane w ustawach dość skomplikowanym językiem dla człowieka nie mającego styczności z prawem. Taki stan faktyczny powoduje wychodzenie z różnorakimi inicjatywami edukacyjnymi przez odpowiedzialne instytucje jak Ministerstwo Finansów. Mają one na celu zwiększenie świadomości o ich prawach, co w konsekwencji sprzyja ochronie ich przestrzegania. Istotny brak wiedzy o podatkach sugeruje jednak zwiększenie intensywności i częstotliwości przeprowadzania akcji edukacyjnych, zwłaszcza tych skierowanych do osób mniej wykształconych. Dodatkowo inicjatywy edukacyjne mogą wychodzić także od ośrodków nauki, poprzez organizowanie otwartych konferencji naukowych czy wykładów prowadzonych przez praktyków lub dydaktyków chcących poszerzać swoje doświadczenia, przyczyniając się przy tym do zwiększania wiedzy podatników.

\section{BIBLIOGRAFIA}

Bojkowski T., 2004, Wolności oraz prawa konstytucyjne podatnika, „Ruch Prawniczy, Ekonomiczny i Socjologiczny Rok LXVI - zeszyt 3".

Gomułowicz,A., Małecki J., 2011, Podatki i prawo podatkowe, Lexis Nexis, Warszawa.

Informacja dotyczaca rozliczenia podatku dochodowego od osób fizycznych za 2016 rok, 2017, Departament Podatków Dochodowych, Warszawa, 2017

Interpretacja ogólna ministra finansów z 29 grudnia 2015 r., PK4.8022.44.2015.

Konstytucja Rzeczpospolitej Polskiej z dnia 2 kwietnia 1997 r., Dz.U. nr 78, poz. 483.

Mastalski R., 2016, Tworzenie prawa podatkowego a jego stosowanie, WoltersKluwer, Warszawa, Niesiobędzka M., 2006, Spoteczna świadomość podatków: czy potrafimy przypomnieć sobie, jakie podatki musieliśmy zapłacić?, „Optimum: Studia Ekonomiczne”, nr 1(29).

Polski system podatkowy wedlug uczestników VIII Kongresu Podatków i Rachunkowości KPMG, 2018, KPMG w Polsce, luty. 
Raport z badania ilościowego przeprowadzonego na zlecenie Związku Przedsiębiorców i Pracodawców Czego Polacy nie wiedza o podatkach?, 2017, Warszawa.

Ustawa z dnia 29 sierpnia 1997 r. - Ordynacja podatkowa, tekst jednolity: Dz.U. 1997, nr 137, poz. 926.

Wyrok TK z dnia 27 listopada 2007 r., sygn. akt SK 39/06, LEX 318047.

[www1] http://www.doradcy.krdp.pl/aktualnosciall.php/all/10/4673 [dostęp 18.02.2018].

[www2] http://www.mf.gov.pl/ministerstwo-finansow/dzialalnosc/dzialalnoscedukacyjna/projekty/-/asset_publisher/2IKb/content/narodowa-loteria-paragonowa [dostęp 18.02.2018].

[www3] http://www.mf.gov.pl/ministerstwo-finansow/dzialalnosc/dzialalnoscedukacyjna/projekty/-/asset_publisher/2IKb/content/wez-paragon-wez-paragon-ze-soba [dostęp 18.02.2018].

[www4] http://www.mf.gov.pl/ministerstwo-finansow/dzialalnosc/dzialalnoscedukacyjna/projekty/-/asset_publisher/2IKb/content/finansoaktywni-misja-\%E2\%80\%93uczciwie-place-podatki [dostęp 18.02.2018].

[www5] http://www.mf.gov.pl/ministerstwo-finansow/dzialalnosc/dzialalnoscedukacyjna/projekty/-/asset_publisher/2IKb/content/wielki-test-o-podatkach-fiskus-odkuchni [dostęp 18.02.2018].

[www6] http://www.mf.gov.pl/ministerstwo-finansow/wiadomosci/aktualnosci/ministerstwofinansow2/-/asset_publisher/M1vU/content/rozpoczynamy-akcje-szybki-pit-1 [dostęp 18.02.2018].

[www7] http://www.rp.pl/Budzet-i-Podatki/170429449-Pomoc-podatnikom-wciaz-niezbedna-takjak-edukacja-podatkowa.html [dostęp 18.02.2018].

\title{
EDUCATION IN THE FIELD OF WORKING OF TAX SYSTEM AS THE PROTECTION OF THE TAXER'S RIGHTS
}

\begin{abstract}
The article reviews the rights of taxpayers included in both the Basic Law and the Tax Ordinance, and to confront them with the taxpayers' knowledge of the basics of the tax system. Showing how important is the problem of public unconsciousness in the context of tax knowledge based on the results of the conducted research is also to pay attention to the necessity of organization educational actions and initiatives. Such projects, carried out mainly by the Ministry of Finance and the National Chamber of Tax Advisors are extremely important and should be intensified as part of increasing taxpayers' awareness of the duties and rights they are entitled to. The article also lists examples of such initiatives taking place in the past.
\end{abstract}

Keywords: taxpayer's rights, tax system in Poland, tax education. 